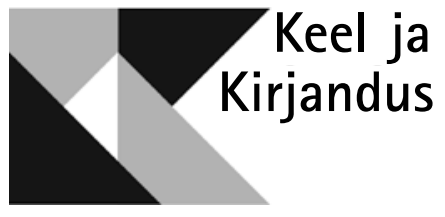

\title{
KIRJANDUSVÄLJA TOIMIMISVIISIST JAAN KROSSI SAKSA RETSEPTSIOONI NÄITEL
}

\author{
CORNELIUS HASSELBLATT
}

$J$ aan Kross on kahtlemata tõlgituim XX sajandi eesti kirjanik ja juba sel põhjusel huvitav uurimisobjekt, kui tahetakse vaadelda, kuidas toimib ühe kirjanduse vastuvõtt mingis teises keeleruumis. Saksa keeleala puhul on eriti kütkestav asjaolu, et vahepeal elav ja jõuline Krossi retseptsioon on praeguseks raugenud. Sellest tähelepanekust lähtudes tahan käesolevas artiklis küsida, miks see nii on. Taustaks kasutan Pierre Bourdieu (nt 1983, 1985) kirjandusvälja kontseptsiooni, mis on andnud mitmeid tõukeid kirjanduse uurimiseks erinevatest vaatevinklitest, mida vanemas kirjandusteaduses poleks peetudki kirjanduse kui kunstinähtusega tegelemiseks. Teooriad muidugi tulevad ja lähevad, ning ma ei tahaks langeda teoreetilise dogmatismi lõksu, oletades, et just see ongi viimane tõde ja kõik endised metodoloogiad on ajast ja arust. Kuid minu meelest on veenvalt näidatud, et näiliselt kirjandusvälised tegurid, nagu majanduselu, raha, ühiskondlik positsioon jne, mängivad rolli ka kirjanduselu korraldamisel ja kirjanduse enese väärtustamisel. Bourdieu räägib teatavasti sellega seoses erinevatest kapitalidest - sotsiaalsest, sümboolsest, kultuurilisest või majanduslikust kapitalist.

Süvenemata küll Bourdieu teooria üksikasjadesse, tahan siinses artiklis kirjandussotsioloogilisest vaatevinklist vaadelda, kuidas on kulgenud ühe

* Artikkel lähtub vastavatest peatükkidest autori saksakeelses monograafias eesti kirjanduse retseptsioonist Saksamaal (Hasselblatt 2011), kuid on siin mugandatud, lühendatud ning edasi arendatud. 
autori välisretseptsioon ning millised tegurid on seejuures mõju avaldanud. Selleks on kõigepealt vaja määratleda, mida ma mõistan retseptsiooni (või antud juhul väli s retseptsiooni) all. Siin kasutatakse seda mõistet kõige laiemas mõttes (vrd Hasselblatt 2016: 12), nii et selle alla kuulub iga teose (autori) tähelepanemine, lugemine, esitlemine, tõlkimine või väljaandmine, teisisõnu: huvi keskmes on igasugune võimalik mõju (sks Wirkungsgeschichte, vrd Grimm 1977: 28-31). Kui mingi tekst tõlgitakse teise keelde ning trükitakse, on seegi siinses arusaamas juba retseptsiooni ilming - vaatamata sellele, kui palju teksti loetakse või mis mõju ta tegelikult avaldab.

Jaan Kross on kahel põhjusel huvitav objekt välisretseptsiooni uurimiseks. Esiteks on ta üks väheseid eesti autoreid, kelle puhul võib üldse rääkida uurimiseks piisavalt ulatuslikust välisretseptsioonist; ning teiseks on autor ise - ükskõik, kas teadlikult või tahtmatult - võtnud oma teoste välismaise vastuvõtu ja väljaandmisega seoses seisukoha, millega on võimalik polemiseerida. Nimelt kirjutas ta: „Muuseas - välismaised kirjastused on mõnelgi puhul pannud mulle ette või taotlenud mu nõustumist mõne seal kuskil välja anda kavatsetud raamatu pealkirja muutmiseks, selle asendamiseks, nagu öeldud, paremini m üüv a pealkirjaga. [---] Üldjuhul sellised ettepanekud mulle ei meeldi. // Mulle tundub, et ma pole ju kirjutanud ega pealkirjastanud oma raamatut äritsemisobjektiks suhteliselt kõrvalistele tegelastele" (Kross 2003b: 97).

Lihtsustatult väljendades on siin näha hoiak, et raha on räpane asi ja kunst on õilis tegevus. Täpselt samasugune hoiak oli kirjanikel Euroopas XVIII sajandi lõpul ja XIX sajandi algul, kui Bourdieu sõnul moodne kirjandusväli hakkas välja kujunema: ka siis olid kirjanikud veendunud võimatuses taandada oma teos äriobjekti tasemele (Bourdieu 1985: 16). Lugeja pangu aga tähele, et Kross kasutab tegusõna „äritsema”, mis on kindlasti negatiivse kõlaga kui mitte pejoratiivne, ta oleks võinud kirjutada ka „äriobjektiks”. Aga „äritsema” tähendab seletava sõnaraamatu järgi '(ebaseaduslikku) äri ajama; kaubitsema, kauplema; hangeldama, sahkerdama' (EKSS: 591). Nii et Kross loob distantsi enda tegutsemisviisi ja „äritsemismaailma” vahele, eirates asjaolu, et tema ise just kirjutamisest ära elaski. Ja kuidas tuleb tsiteeritud lauses mõista lauseosa „suhteliselt kõrvalistele tegelastele”? Kas pole iga välismaalane, kes tahab midagi eesti kirjandusest lugeda ning vajab selleks keeleoskamatuse tõttu tõlget, mingil määral „kõrvaline tegelane”? Ning lõpuks: ükskõik, kas see meile või autorile meeldib või ei meeldi, enamikus maades on kirjanduselu korraldatud suuremalt jaolt üldiste majandusreeglite järgi, mis tähendab, et äri on selle lahutamatu koostiselement. Just sellepärast tasub, vastupidiselt Krossi enda hoiakule või soovunelmale, vaadata kirjandust ka sellest aspektist.

\section{Saksakeelsed kirjandusväljad}

Saksa keeleruumi näol on tegemist enama kui üheainsa kirjandusväljaga, eriti kui vaatleme seda ajaloolises perspektiivis (ka Ute Wölfel 2005: 7 kõneleb saksakeelsetest väljadest mitmuses). Kui 1970. aastate algul ilmusid esimesed Krossi teoste saksakeelsed tõlked, võib rääkida isegi neljast erinevast väljast (Hasselblatt 2015a: 60): Saksa Demokraatlik Vabariik, Saksamaa Liitvabariik 
(koos Šveitsi ja Austriaga, mis on siiski marginaalsed), Nõukogude Liit (koos sinna de facto inkorporeeritud Eestiga) ning nn Välis-Eesti, st eestlastest pagulaskond Rootsis, Põhja-Ameerikas ja Austraalias.

Neist viimane pole Krossi puhul tähtis, sest pagulasringkonnad ei tegelnud eriti palju tõlkimisega ning peaaegu üldse mitte „kodueestlaste” loominguga. Saksakeelses tõlkes on neil ette näidata vaid mõned raamatud, nagu Bernard Kangro (1954) saksakeelne kogumik või Ants Orase (1964) koostatud luuleantoloogia. Viimane sisaldab küll Betti Alveri, Uku Masingu ja Heiti Talviku luuletusi, kuid muidugi sõjaeelsest ajast.

Saksa DV ja Nõukogude Liidu väljad on aga seotud eesti kirjanduse ning niisiis ka Krossi vastuvõtuga saksakeelses ruumis. Nõukogude Liit omab tähtsust, kuna seal ilmus 1971. aastal esimene saksa keelde tõlgitud Krossi tekst („Neli monoloogi”, Kross 1971). Nimelt ilmus ajavahemikul 1946-1991 Moskvas saksakeelne kuukiri Sowjetliteratur (Nõukogude Kirjandus), mille väljaandjaks oli Nõukogude Kirjanike Liit. Sama väljaanne, kuid mitte identse sisu ega toimetusega, eksisteeris ka inglise (Soviet Literature), prantsuse (Lettres soviétiques) ja hiljem veel viies keeles (Hasselblatt 2011: 213). On raske kindlaks teha, kuivõrd selline väljaanne oma silmas peetud lugejateni jõudis. Kuna tegemist on väljaspool saksa keeleala loodud, aga saksa keelealale mõeldud materjaliga, olen sellist tegutsemisviisi nimetanud pseudoretseptsiooniks (vrd Hasselblatt 2015b: 229-230), sest on küsitav, kas tegu on „ehtsa” vastuvõtu või huviga. Siin ei tooda ju saksa vaatevinklist midagi sisse, vaid see on olnud Moskva-poolne väljaviimine, eksport - nii et on üldse kaheldav, kas siin saab rääkida Bourdieu mõttes olemasolevast kunstiteosest, mis eeldab tuntust ja tähelepanu (Bourdieu 1983: 318). Teisest küljes ei saa eirata, et seda ajakirja telliti ja loeti. Tänapäeval on Sowjetliteratur esindatud vähemalt kuuekümnes saksa (teaduslikus) raamatukogus (Hasselblatt 2011: 213). Samuti pole välistatud, et sel ajakirjal, kus peatselt ilmusid teisedki Krossi tekstid (Kross 1972, 1976), oli mõju Saksa DV kirjandusvälja mingile osale, nimelt kirjastusmaailmale, kus jälgiti võrdlemisi täpselt, mida suur vend Moskvas tegi.

Nii ehk ei ole juhus, et esimene Krossi raamat, mis Saksa DV-s kirjastati, oli osaliselt juba Moskvas ilmunud. See sisaldas Sowjetliteraturis ilmunud teksti ning lisaks „Mihkelsoni immatrikuleerimise” (Kross 1974). Olgu aga öeldud, et antud juhul toimus Krossi tekstiga tutvumine vene keele kaudu, sest Ida-Saksa kirjastaja Margit Bräuer oli lugenud „Nelja monoloogi” venekeelset tõlget ajakirjas Družba narodov ning oli sellest vaimustusse sattunud (Bräuer 1990: 109). Sellega algaski saksa keeleruumis Krossi retseptsioon raamatute kujul. Viie aasta pärast avaldati ühes antoloogias „Taevakivi” (Kross 1979), kuid järgmised raamatud, „Kolme katku vahel” ja „Keisri hull”, ilmusid alles kümmekond aastat hiljem, juba Saksa DV lõpuperioodil vastavalt 1986. ja 1988. aastal. Ma muidugi ei ütleks, et Bourdieu teooria ei tööta sotsialistlikuks nimetatud ühiskondades (vrd Wölfel 2005), aga kindel on, et sealsetel kirjandusväljadel on aktiivsed hoopis teistsugused tegurid kui turumajanduslikes tingimustes. Sellepärast ei käsitle ma siinses artiklis Saksa DV retseptsiooni üksikasjalikumalt (vt selle kohta Burmeister 1990; Hasselblatt 2011: 187-193), vaid keskendun läänesaksa väljale kui kõige suuremale ja siiamaani olemasolevale kirjandusväljale. 
Uue autori esitlemine võib toimuda kahel viisil: kas lihtsalt raamatut kirjastades ning läbilöögi peale lootes või ajakirjanduse kaudu kirjandusvälja ette valmistades ja autorit tutvustades. Krossi ja läänesaksa turu puhul võib rääkida teise variandi kasutamisest, mis tuleb osaliselt ka sellest, et läänesaksa läbikäimine idasaksa kultuuriväljaga oli kõikuv. Mõned ringkonnad arvestasid sellega, teised jälle mitte. Nii et Krossi retseptsioon läänesaksa väljal algas hüplikult ja konarlikult, kuni läbimurdeni ühe eduka romaaniga. Kuid läbimurdele ei järgnenud pidev kohalolek, sest kümne või viieteistkümne aasta pärast oli buum enam-vähem vaibunud. Niisiis võib rääkida Krossi saksa retseptsiooni kolmest faasist: ettevalmistav tõusuajajärk kuni „Keisri hulluni” (1990), „Keisri hullule” järgnev buum, mis kestis umbes kümme aastat, ja siis uue sajandi alguse mõõn.

Esimene Krossi käsitlus või pigem ainult tutvustus läänesaksa ajakirjanduses toimus kõrvalises väljaandes, nimelt vähese levikuga baltisakslaste aastaraamatus. Ajaloolane Arved von Taube tutvustas romaani „Kolme katku vahel" esimest kaht osa, rõhutades, et teda huvitab peamiselt ajaloo kujutamine. Kuigi ta tsiteeris nii Pärt Liase arvustust (1971) kui ka Arvo Mägi kirjanduslugu (1968), olid ta teadmised siiski lünklikud, kui ta väitis näiteks ilma mingile allikale viitamata, et Krossi peeti „veendunud sotsialistiks” (von Taube 1977: 205).

Teine artikkel oli palju kompetentsem ning ilmus üsna laia levikuga poliitilis-ajaloolises erialaajakirjas Osteuropa, mille toimetus asus tollal Kölnilähedases Aachenis. Kölni ülikoolis oli aga õppeaastal 1977/78 külalisteadlasena loenguid pidanud poola slavist ja esseist Andrzej Drawicz (1932-1997), keda ajakirja toimetus küllap märkas, ning nõnda tutvustas Drawicz (1979) seitsmeleheküljelises käsitluses Krossi loomingut venekeelsete tõlgete kaudu.

Kolmandat korda tehti Krossist juttu juba „korralikus” kirjandusajakirjas, kuigi ka siin on veel juhuslikkuse märke. Ajavahemikul 1981-1986 ilmus Soome-Saksa koostöös kuus paksu aastaraamatut Trajekt (vt selle kohta Hasselblatt 2011: 275-280, 2015b: 427-435). Trajekti alapealkiri oli „Lisandusi soome, lapi ja eesti kirjandusele" ning seega on tegemist märkimisväärse faktiga: ühe saksakeelse kirjandusajakirja alapealkirjas on mainitud eesti kirjandust. See seletub sellega, et Trajekt kasvas välja Soomes ilmunud saksakeelse kirjandusliku aastaraamatu toimetuse lõhenemisest. Soomes oldi Eesti olemasolust muidugi teadlikud, ka külma sõja ajal. Nii saigi Otava kirjastuse rahastatud uus saksakeelne kirjandusajakiri sellise alapealkirja. Otava leidis Saksamaalt koostööpartneriks Klett-Cotta kirjastuse, mis pidi hoolitsema ajakirja levitamise eest saksa kirjandusväljal. Teatud mõttes on siin veel pseudoretseptsiooni jälgi: kuigi toimetus koosnes enamikus sakslastest, anti ajakirja välja Soome rahaga ning põhirõhk oli soome ja soomerootsi kirjanduse ekspordil. Ometi jõudis see ka saksa kirjandusväljale, aastaraamatut arvustati suuremates ajalehtedes, näiteks Neue Zürcher Zeitungis ja Die Zeitis, mis on saksakeelsel kirjandusväljal väga olulised (vt allpool).

Trajekti kolmandas numbris (1983) ilmus Helga Viira tõlkes Krossi novell „Marrastus”, mida toimetus oli tublisti töödelnud. See oli esimene LääneSaksamaal ilmunud Krossi tekst, mis tuli trükist kevadel 1984 Soomes ning Saksamaal jõudis müügile sama aasta sügisel. Varem oli ainult ühes Lääne- 
Berliini (mis ju rahvusvahelise õiguse kohaselt ei olnud Lääne-Saksamaa osa) ajakirjas DSF-Journal ilmunud Krossi „Nelja monoloogi” katkend, mis pärines 1974. aasta Saksa DV väljaandest (Kross 1983; seda ajakirja andis välja Saksa-Nõukogude Sõprusühing DSF, mis oli Saksa DV-s massiorganisatsioon kuue miljoni liikmega, kuid läänes marginaalne ning osaliselt isegi keelatud).

Trajekti toimetus andis välja ka raamatusarja, milles ilmusid peamiselt soome kirjanduse saksandused, kuid juba päris alguses oli kavas anda välja ka eesti kirjandust. Sarja esimene raamat oli ilmunud 1980. aastal ning sügisel 1983 kirjutas mulle toimetus, et Krossi „Nelja monoloogi” väljaandmine olevat juba „kaua olnud kavas”. Aga autoriõigustega olevat sekeldusi. Need seisnesid selles - siin tuleb mängu eelmainitud mitmekülgne kirjandusväli -, et Trajekti toimetus tahtis kasutada Saksa DV 1974. aasta väljaannet ning oli Aufbau kirjastuselt litsentsi küsinud. Idasakslased tahtsid enne litsentsi andmist aga NSV Liidu Riikliku Autoriõiguste Agentuuri (VAAP-i) käest saada kinnitust, et neil, niisiis VAAP-il, ei ole õigusi. Alles siis julges Aufbau müüa või anda litsentsi Otavale (Trajekti toimetus 1983) ning raamat ilmus 1985. aastal. See oligi sama vene keelest tehtud ja 1974 ilmunud tõlge, aga nüüd vähemalt (käesolevate ridade kirjutaja poolt) originaaliga võrreldud ning kergelt toimetatud.

Krossi hüppeline tulemine saksakeelsele kirjandusväljale kiirenes või tihenes selsamal 1985. aastal, kui Kross viibis esimest korda Lääne-Saksamaal. Formaalses mõttes oli see töövisiit, ta otsis materjali oma teoksil oleva romaani („Vastutuulelaev”) jaoks ning elas neli nädalat Hamburgi lähedal Bernhard Schmidti viimases töökohas. Aga esimene läänesaksa turul ilmunud raamat ning autori kohalviibimine tegid võimalikuks kaks kirjandusõhtut, üks Kieli raamatukaupluses, teine Hamburgi ülikooli soome-ugri instituudis. Need sündmused kajastusid ka kohalikus ajakirjanduses.

Algus oli tehtud ning kui Kross kahe aasta pärast uuesti Tallinna sõpruslinnas Kielis käis, tuli linnaraamatukokku juba üle saja inimese, mis on ühelt peaaegu täiesti tundmatult maalt tulnud suhteliselt tundmatu autori jaoks küllalt hea tulemus. Muidugi, ega see maa enam päris tundmatu olnud, sest tasapisi hakkas laulev revolutsioon ka Lääne-Saksamaal huvi äratama. See oli arvatavasti tähtsam kui 1986. aastal Saksa DV-s ilmunud kolmeköiteline „Kolme katku vahel” Helga Viira tõlkes, mida ainult marginaalselt ära märgiti. Teisel Saksamaal ilmunut pandi vaevalt tähele Lääne-Saksamaal, küll aga Šveitsis, kus ilmus veebruaris 1988 Eesti Vabariigi 70. aastapäeva puhul pikk artikkel, mille üks teema oli Krossi „Kolme katku vahel” ja selle tõlge (Neidhardt 1988a). Sama artikkel ilmus viis kuud hiljem ka Lääne-Saksamaal (Neidhardt 1988b), mis pole juhus: äärtelt (antud juhul Šveitsist) ollakse varem valmis teistele äärtele vaatama kui keskusest. Seetõttu on arusaadav, et alles pärast öölaulupidusid ning laulva revolutsiooni nime sündimist tahtis ka üks Lääne-Saksamaa suur ajaleht midagi Eesti kohta avaldada. Marginaalsete äärte hulka tuleb arvata ka ajakiri Estonia, mis hakkas ilmuma 1985. aastal ning saavutas oma levikuga (umbes 70 tellijat Saksamaal, vt Hasselblatt 2011: 296) väikse lugejaskonna. Krossi kohta ilmusid selle esimestes aastakäikudes mõned artiklid.

1989. aastal toimus kolm sündmust. Saksa DV-s jõudis märtsis või aprillis 1989 poelettidele „Keisri hull” (Kross 1988), kuigi tiitellehele oli trükitud aastaarv 1988 (Hasselblatt 2011: 192). See ei jäänud täielikult märkamata ka 
läänes, kuigi, nagu öeldud, Saksa DV kirjandusväli oli eri asi. Prantsusmaal ilmus sama aasta sügisel samuti „Keisri hullu” tõlge (Kross 1989), mida märgati. Ja siis korraldas evangeelne akadeemia Alam-Saksi Loccumis suurejoonelise autorikonverentsi, mille puhul Jaan Kross ja Ellen Niit kohale sõitsid.

Evangeelsed akadeemiad Saksamaal on küll puhtformaalselt kirikuasutused, kuid nad tegutsevad üsna iseseisvalt ega tegele ainult kiriklike teemadega, vaid täiskasvanuhariduse ja igasuguste ühiskondlike arengutega. Kohtumised kirjanikega, kuhu kutsutakse peale huvitatud publiku ka kirjastajaid, kirjandusloolasi, tõlkijaid, ajakirjanikke jne, on Saksamaal üldlevinud ja populaarsed sündmused. Kõne all olevas Loccumi akadeemias olid varem külalisteks kirgiisi kirjanik Tšõngõz Ajtmatov ning pärastine Nobeli rahuauhinna laureaat Elie Wiesel. Mõlemalt autorilt oli saksa raamatuturul saadaval piisavalt kirjandust, nüüd aga kutsus akadeemia külla peaaegu tõlkimata autori. Sellest oli konverentsi korraldaja Olaf Schwencke teadlik ning oma avasõnavõtus avaldas ta lootust, et konverentsiga õnnestuks „läbimurre” (Schwencke 1990: 16), viidates Saksa DV-s ilmunud „Keisri hullule”.

Kui tavaliselt algab retseptsioon „kuulsast romaanist”, nagu oli mitmel maal, kus „Keisri hull” oli esimene tõlge, ka näiteks naabritel Soomes (1982) ja Rootsis (1983), siis Saksamaal oli asi teistmoodi. Esiteks oli algust tehtud juba varem ja teiste tekstidega (vt Kross 1974, 1985, 1986), aga ainult pooleldi, st Saksa DV-s, ja tagasihoidlikumate tulemustega, sest varased saksakeelsed tõlked pole võrreldavad „Keisri hullu” plahvatusliku menuga Soomes või Prantsusmaal. Teiseks oli läänesaksa retseptsiooni algusaastate suurim sündmus populaarteaduslik konverents, mitte romaani avaldamine ning selle arvustamine (nagu mainitud puhkudel Soomes või mujal). Siin mängib kindlasti oma rolli Saksamaa erinev positsioon (mainitud mitmekesine kirjandusväli) ning poliitiline olukord: Loccumi konverents leidis aset nädalavahetusel enne sellesama aasta (aastakümne? sajandi?) kõige kuulsamat neljapäeva, nimelt Berliini müüri kokkuvarisemise päeva 9. novembril 1989. aastal.

3.-5. novembrini korraldatud konverents oli märkimisväärne. Kohal oli üle saja inimese, nende hulgas ka kirjastajaid, tõlkijaid, kirjandusteadlasi, ajaloolasi ja ajakirjanikke. Selle tulemusena ilmus järgnevatel kuudel tõepoolest üht-teist Krossi kohta ning kolme kuu pärast oli leitud ka suur LääneSaksa kirjastus Hanser, mis oli valmis Krossi teoseid kirjastama. Mainitud fakt, et neli päeva pärast konverentsi lõppu algas müüri kokkuvarisemisega ka Ida-Saksa kirjastuste kokkuvarisemine (või pigem nende süstemaatiline hävitamine, vt Links 2009), mängib siin muidugi oma rolli.

\section{„Keisri hullu” tähelend}

Kui kolm kuud pärast Loccumi konverentsi pühitseti Tallinnas Krossi 70. sünnipäeva, tuli peaaegu sama Loccumis esinenud seltskond Eestisse (ainult prantsuse tõlkija Jean-Luc Moreau ei saanud tulla, sest ta pidi „Professor Martensi ärasõitu” tõlkima) ning Loccumi korraldaja Olaf Schwencke sai juubilarile üle anda konverentsi kogumiku. Selle sissejuhatuses konstateeris ta uhkelt: „Selle kogumiku ettevalmistamisel sain hea uudise, et Müncheni kirjastus Hanser tahab välja anda Jaan Krossi kogutoodangut, alates „Keisri hullust"” (Schwencke 1990: 11). 
Loccumi konverentsi kogumik polnud laia levikuga publikatsioon, aga see sattus „õigete” levitajate, st suurte ajalehtede ajakirjanike kätte, nagu tõestab üks augustis 1990 ilmunud artikkel ajakirjas Die Welt (Serke 1990). Väga mitmekesisel saksakeelsel ajakirjandusturul olid tol ajal ainult viis või kuus päevalehte tõesti suure, st kogu keeleala katva levikuga, ning Die Welt oli üks neist. Teised olid Süddeutsche Zeitung, Frankfurter Allgemeine Zeitung, Frankfurter Rundschau, Neue Zürcher Zeitung ja ehk veel Die Tageszeitung. Lisaks olid ajakirjandusväljal olulised nädalalehed Die Zeit ja Das Sonntagsblatt.

Die Welti ajakirjanik oli Krossiga Helsingis vestelnud ning selle põhjal kirjutatud tutvustavas artiklis mainiti ka peatselt Lääne-Saksamaal ilmuvat „Keisri hullu”. Tõlge ilmuski 1990. aasta hilissuvel (Kross 1990b) ning sai suure tähelepanu osaliseks, peamiselt muidugi seetõttu, et selle välja andnud Hanseri kirjastusel on saksa kirjandusväljal väga hea positsioon. Mingit ametlikku edetabelit pole, aga nagu ajakirjandusväljal, võib ju ka ilukirjanduslike kirjastuste väljal rääkida umbes „viiest või kuuest suurest”. Tol ajal kuulusid sinna Fischer, Rowohlt, Suhrkamp, Luchterhand, Hoffmann und Campe ja Hanser. Samal ajal avaldas Hanser näiteks niisuguseid rahvusvaheliselt tunnustatud autoreid nagu Umberto Eco ja Milan Kundera.

Hanseri väljaanne oli sama kergelt toimetatud Helga Viira tõlge, mis poolteist aastat varem Saksa DV-s oli ilmunud. Toimetamine kõrvaldas peamiselt mõned stiilivead, aga mõni uus (tähtsusetu) viga tuli ka juurde, nagu vale daatum 26. veebruar 1836 (õige on 25. veebruar). Üldiselt võeti raamat vastu kui uudisraamat, mitte kui kordustrükk, kuigi osa arvustajatest viitas asjaolule, et sama tõlge oli juba varem Saksa DV-s ilmunud.

Kross, kes 1990. aasta sügisel seoses uute raamatutega üsna palju ringi reisis (Veiper 1990), esitles oma romaani isiklikult Frankfurdi raamatumessil ning „Keisri hullu” Hanseri väljaannet arvustati saksa ajakirjanduses ulatuslikult. Kokku ilmus umbes - täpset arvu pole võimalik anda - kolmkümmend arvustust (vrd Hasselblatt 2004: 69-70; Kabur, Palk 1997: 243-244) ning esindatud olid kõik olulisemad, üleriigilise levikuga ajalehed. Mitte kõik arvustused ei olnud juubeldavad või ainult positiivsed, aga enamik oli seda küll. Kõige tähtsam oli ilmselt massiline kajastamine. Kuna sellele järgnes võrdlemisi ruttu samas kirjastuses Krossi teine romaan (vt allpool) ning „Keisri hullu” taastrükid kuulsas taskuraamatute kirjastuses 1994., 2003. ja 2004. aastal, näis tee kaanonisse olevat sillutatud.

\section{„Professor Martensi” saabumine}

Poolteist aastat pärast „Keisri hullu”, märtsis 1992, ilmus Hanseri kirjastuselt „Professor Martensi ärasõidu” saksakeelne tõlge. Kirjastuse reklaam oli veel suurejoonelisem kui „Keisri hullu” puhul, sest nüüd võidi ju viidata eelmisele romaanile. Ajalehte Die Zeit ostis Hanser kolmandiku lehekülge, et reklaamida kolme uut romaani, millest üks oli „Professor Martensi ärasõit”, ning samal ajal levitati paberist järjehoidjaid, kus Kross oli esindatud koos Primo Levi, Italo Calvino, Milan Kundera ja Peter Høegi uudisraamatutega (Hasselblatt 2011: 321).

„Professor Martensi” vastuvõtt oli paremgi kui „Keisri hullu” oma, kui silmas pidada, et esiteks oli arvustuste hulk umbes sama kui mitte suurem (vrd 
jälle Hasselblatt 2004: 70-71; Kabur, Palk 1997: 244-246), kusjuures ka ilmumiskohad olid „õiged”, ja teiseks ei olnud seekord üldse negatiivset vastukaja. Kui „Keisri hullu” kohta oli siin-seal väljendatud tagasihoidlikku kriitikat või küsitavusi, siis „Professor Martensi” vastuvõtt oli osaliselt lausa juubeldav. Autor oli nüüd tuttav, väli oli ette valmistatud, osa publikust juba ootas järjekordset Krossi romaani. 1990. aastate algul oli ka Krossi nime seostamine Nobeli preemiaga (millest oli saksa keeleruumis teadaolevalt esimest korda juttu 1985. aasta oktoobris; Verg 1985) oma kõrgpunktis, kui võtta arvesse, et sügisel 1991 pealkirjastas üks ajaleht peatselt välja antavat auhinda käsitleva artikli väitega, et favoriit olevat üks eestlane (vrd Hasselblatt 2011: 337). Romaani suurema edu põhjuseks on ka see, et Martensiga oli saksa lugejal kergem samastuda. Kui seoses „Keisri hulluga” oli veel võimalik mõtelda, et tegemist on mineviku kauge tsaaririigi ühe poolhullu spetsiifilise probleemiga, siis Martens on ajaliselt lähemal ning osaliselt lausa keset Euroopat. Teine peategelanegi on sakslane, tegevus puudutab Saksamaad, esinevad tuttavad linnad, nagu Göttingen, Frankfurt, Hamburg, Berliin, Kassel ja Hannover. Lõpuks on ka temaatika universaalsem ning filosoofilisem: saksa lugejal polnud vaja süveneda kauge maa tundmatusse ja keerulisse ajalukku, Martensi muuhulgas tõe ja lojaalsusega seotud probleemid olid kohe adutavad.

Ka „Professor Martensi ärasõit” ilmus kolme aasta pärast taskuväljaandes, kuid enne seda oli saksa turule tulnud juba järjekordne nimetus. Nimelt olid Saksamaa kirjandusväljal teisedki kirjastused avastanud eesti kirjanduse ning üks neist, väike Maini-äärses Frankfurdis asuv kirjastus nimega Dipa, oli Hanseriga kokkuleppele jõudnud: Hanser, kes põhimõtteliselt tahtis välja anda kogu Krossi, mingu edasi suurte romaanidega, aga jätku väiksele Dipa kirjastusele Krossi lühemad proosapalad. Nõnda ilmuski Krossi novellivalimik (Kross 1994c) ja niisugusest jaotusest võitsid mõlemad kirjastused, sest Hanser ei jõudnud (või ei julgenud?) kõiki Krossi raamatuid nii ruttu välja anda ning Dipa, kus selleks ajaks olid ilmunud üks eesti novelliantoloogia ning Maimu Bergi, Asta Põldmäe, Mati Undi ja Arvo Valtoni raamatud, sai ka kuulsast nimest kasu lõigata. Samuti lootsid kirjastused sel viisil teineteist toetada: ehk ostab „Professor Martensist” vaimustunud lugeja ka mõne Dipa raamatu ja vastupidi.

Selline tööjaotus on võib-olla ebaharilik, sest tavaliselt hoolitsevad kirjastused „oma” autori eest ega taha teda teistele loovutada, eriti kui kirjanik on paljutõotav. Igatahes ei ole selline hajumine iseloomulik kirjandusväljale, kuid kriitika reageeris sellele esialgu positiivselt, isegi tänulikult, kõneldi „,äraproovitud tööjaotusest” (Gauß 1995). Teisest küljest pole aga, eriti tagantjärele vaadates, välistatud, et lõhenemine tuli kirjaniku retseptsioonile kahjuks.

Seda kahtlust näib kinnitavat teinegi asjaolu. Nimelt samal ajal (kevadel 1994, kandes küll aastaarvu 1993) ilmus saksa keeles Krossi novell „Vandenõu" - ja mitte Hanseri ega Dipa, vaid Bibliotheca Baltica kirjastuses, millel pole saksa kirjandusväljal mingit positsiooni ja on isegi küsitav, kuivõrd ta sinna üldse kuulub, sest selles kirjastuses välja antud raamatud kannavad Eesti ISBN-numbrit. Ilmumiskohaks oli Tallinn, levitamiskohaks Hamburg, kuid saksa turule jõudsid need raamatud vaevaliselt. Arvustusi selliste publikatsioonide kohta saksa ajakirjanduses üldiselt ei leidu. Nii et esialgu ei näi sel olevat mingit pistmist Krossi retseptsiooniga. Pikemas perspektiivis pole seos siiski välistatud, sest juhtus nii, et 1994. aastal Dipa kirjastuses välja 
tulnud Krossi novellikogumik kandis täpselt sama pealkirja nagu Tallinnas trükitud „Vandenõu”. Kuid sisu oli hoopis teistsugune: mitte ainult tõlge polnud teine, vaid Dipa raamatus oli viis Krossi novelli (lisaks niminovellile veel „Minu onupoja jutustus”, „Onu”, „Halleluuja” ning „Põgenemine”). Kahe sama pealkirjaga, kuid erineva raamatu ilmumine on muidugi eksitav ning bibliograafidele meelehärmiks.

Vahetult (ja ma arvan, et siiamaani) märgati aga ainult Dipa kirjastuses ilmunud kogumikku. See käes ja „Professor Martens” pagasis, tuli Kross 1994. aasta varasuvel lugemisreisile Saksamaale. Ta käis sel perioodil üsna regulaarselt Saksamaal, kuid see reis oli kõige ulatuslikum. Kolme nädala jooksul esines ta raamatukauplustes, raamatukogudes ja kultuurikeskustes kümnes linnas: Maini-äärses Frankfurdis, Karlsruhes, Stuttgardis, Göttingenis, Oldenburgis, Bonnis, Aachenis, Berliinis, Erlangenis ja Nürnbergis. Silma torkab fakt, et Münchenis, kus asub ometi Hanseri kirjastus, Kross seekord ei esinenud. Üleüldse on huvitav, et reisi korraldas Frankfurdi Dipa kirjastus koos Frankfurdi kirjandusmaja ja Berliini kirjandustööpajaga (literaturWERKstatt Berlin), mitte aga suur ja mainekas Müncheni kirjastaja. See ei pruugi, kuid võib tähendada taas mõranemise märke.

Krossi ringreis Saksamaal oli menukas. Huvi oli suur, lugemisõhtud olid hästi ette valmistatud ja reklaamitud, vastukaja kohalikus ajakirjanduses oli samuti olemas (Schubert 1994). Enamasti luges Kross midagi värskest novellikogumikust, kuid Göttingenis lisas ta ka mõne palakese „Professor Martensi ärasõidust”, kuna romaani tegevus toimub ju osaliselt selles linnas. Väärib märkimist, et kunagi varem (ega hiljemgi) ei ole ühtki eesti autorit nii ulatuslikult ja põhjalikult saksa lugejatele tutvustatud. Arvatavasti pole liialdus öelda, et sel hetkel oli Kross tõusnud eksootiliste kõrvalseisjate hulgast tavaliste, nähtavate, elavate maailmakirjanduse esindajate hulka. Mõnes arvustuses käsitleti teda nagu vana tuttavat, näiteks mainides, et teda ju tuntakse kui „Professor Martensi ärasõidu” autorit ja „kõrgel kunstilisel tasemel” kirjutajat (Klüger 1994).

\section{Haripunktis 1995}

Haripunkti iseloomustab hästi see, et Krossi 75 aasta juubelit veebruaris 1995 tähistati mõnes suures ajalehes (nt Göttler 1995; Krumm 1995), mis pole sugugi tavaline. Selsamal aastal ilmusid kolm Krossi saksakeelset raamatut: lisaks juba mainitud „Professor Martensi ärasõidu” taskuväljaandele ka „Kolme katku vahel” (Kross 1995b) Hanseri kirjastuses (tõlke pealkirjaks sai „Balthasar Russowi elu”) ja „Väljakaevamised” (Kross 1995a) Dipa kirjastuses.

Vastavalt kirjastuste positsioonile saksa kirjandusväljal erines arvustuste hulk. „Väljakaevamisi” arvustati palju vähem, kuigi raamat ilmus kevadel Leipzigi raamatumessiks ning sai juba tänu sellele tähelepanu (tegelikult ilmumine pisut hilines, nii et otseselt mingist „messiboonusest” pole põhjust rääkida). Kuna „Väljakaevamiste” temaatika haarab nii Krossi laagrikogemusi, mis olid Dipa kirjastuses ilmunud novellikogumikust teada, kui ka vanemat ajalugu, mis oli Hanseri kirjastuses ilmunud suurte romaanide keskmes, sai raamatust vahelüli või üleminekuteos. Nõnda võis juhtuda, et seda käsitleti koos romaaniga „Kolme katku vahel”. Näiteks pani ajalehe Die Zeit arvustaja, 
austria kirjanik Karl-Markus Gauß oma arvustusele pealkirjaks „Ohtlikud kroonikad", viidates asjaolule, et mõlema raamatu keskmes on mingi ajalooline tekst kas selle kirjutamise („Kolme katku vahel”) või selle ülesleidmise („Väljakaevamised”) vaatevinklist. Ning tema meelest on romaanidel rohkemgi ühist: Krossi teema on „tõde, ajalookirjutamise, kirjanduse või sõna tõde, mis suudab võimu vastu seista ning peabki vastu seisma" (Gauß 1995). Võimalik, et just tänu „Väljakaevamiste” heale vastuvõtule pääses see kolmandana „Keisri hullu” ja „Kolme katku vahel” järel (vt Gräf 1999) - saksa mitmeköitelisse kirjanduskäsiraamatusse „Der Romanführer” („Romaanijuhataja”), kus seda käsitleti teistest Krossi teostest pikemaltki (vt Steffens 1999).

Sügisel 1995 Hanseri kirjastuses ilmunud romaan „Kolme katku vahel” oli Saksa DV 1986. aasta väljaande uustrükk. Õhukesele paberile trükkimise tõttu oli see üheköiteline raamat 1465 leheküljest hoolimata vaevalt paksem kui varem Hanseris ilmunud „Keisri hull” ja „Professor Martensi ärasõit”. Sedagi romaani retsenseeriti ohtralt (vrd Hasselblatt 2004: 68-69; Kabur, Palk 1997: 241-243), taas eranditult positiivselt, vähemalt kõigis tooniandvates ajalehtedes.

Mõned arvustajad märkisid, et romaan oli juba 1986. aastal Saksa DV-s ilmunud, mis oli muidugi tiitli pöördel korrektselt ära mainitud. Üks arvustaja isegi teadis, et algupärandi pealkiri, millest juba esimeses tõlkeväljaandes oli saanud „Balthasar Russowi elu”, oli „Kolme katku vahel”, mis oli samuti tiitli pöördel ära toodud, aga ainult eesti keeles, ilma tõlketa. Kuskilt oli ta aga algupärandi tähenduse välja nuputanud ning pealkirjastas oma arvustusegi nõnda, imestades, et selline romaan Saksa DV-s üldse ilmuda sai: „Mida tsensorid olid mõelnud, kui nad avaldamisloa andsid? [---] Ometi tuleb Tallinna ohustamine ja vintsutamine ju peamiselt tsaaririigi poolt. Eestikeelne algupärane pealkiri „Kolme katku vahel” oli sapise alatooniga, millega tööliste ja talupoegade riigi kodanikke ei tahetud koormata, mida aga Hanseri kirjastus oleks oma uustrükis võinud taastada" (Bucheli 1995). Niisugune tähelepanek on huvitav ning ausa süvenemise märk. Ka Süddeutsche Zeitungi arvustaja, kelle meelest on tegemist „suure raamatuga”, toob möödaminnes ära originaali pealkirja „Kolme katku vahel”, kuid ta ei süvene teemasse (Göttler 1996). Muide, originaalile täpselt vastav ja minu meelest palju parem (ilusam, põnevam, paljuütlevam...) oli ka ajakirjas Sowjetliteratur ilmunud katkendi pealkiri (Kross 1972: „Zwischen drei Pestseuchen”). Huvitaval kombel on originaali pealkiri jäänud kummitama, sest ühe ingliskeelse ajalooteose bibliograafiast avastasin hiljuti sissekande, mille kohaselt Krossil olevat 1995. aastal Hanseri kirjastuses ilmunud saksakeelne teos just nimelt pealkirjaga „Zwischen drei Pestseuchen" (Wulf 2016: 212).

Olgu kuidas tahes, ka „Balthasar Russowi elu” pealkirja all on romaan „Kolme katku vahel” Saksamaal väga edukalt vastu võetud. Raamat tuli kirjandusväljale lausa kahekordselt, sest kohe esmailmumisele järgnenud aastal anti teos teistsuguse ümbrispaberiga välja raamatuklubi üllitisena (Kross 1996), nii et levik oli veelgi suurem. Oodatult ilmus mõned aastad hiljem (1999) ka taskuraamat (mis formaadi nime küll ära ei ole teeninud, sest trükkimiseks ei kasutatud õhukest paberit), samuti oli sellest romaanist (nagu „Keisri hullustki”) kavandatud kordustrükk ja aastaks 2007 välja reklaamitud, kuid peatselt alanud majanduskriisi tõttu see ei teostunud (Hasselblatt 2011: 332). 


\section{Kainestuv maandumine}

Kui kaks aastat pärast haripunkti ilmus Hanseri kirjastuselt neljas saksa keelde tõlgitud Krossi romaan, võis rääkida sellest, et autor on kanoniseeritud. Seda oli näha juba kaanekujundusest: Hanseri väljaantud esimese kahe Krossi romaani pealkiri oli selgelt suurema šriftiga kui autori nimi, kusjuures kõige esimesel, „Keisri hullul”, oli kiri tunduvalt suurem, „Professor Martensil” oli erinevus juba väiksem. Kolmandana ilmunud „Kolme katku vahel” kaanel olid autori nimi ja pealkiri ühesuurused. Neljandal, „Rakvere romaanil" (Kross 1997a) aga oli ümbrisele pandud hiigelsuurte tähtedega lihtsalt „KROSS” ning keskel $o$ sees oli väikeses kirjas „Jaan”. Ka pealkiri, mis saksakeelses tõlkes oli „Rakvere naised ehk Kodanike ülestõus”, oli ümbrispaberil suhteliselt väikeses kirjas ning mitte ainult oma pikkuse pärast. See näitab selgelt, et autor oli nüüd brändinimi, pealkiri polnud enam kõige tähtsam (vt nelja kaaneümbrise reproduktsiooni Hasselblatt 2011: 331).

„Kaanonisse jõudmine” on näha ka teistel tasanditel: teaduses, esseistikas ning käsiraamatutes või leksikonides. Teaduskäsitlustesse oli Kross jõudnud tegelikult juba Saksa DV lõpuperioodil, kui tema teoseid analüüsiti olemasolevate tõlgete põhjal (Goes 1989, mis oli 1986. aasta loeng). Aga varsti oli võimalik ka magistritöö kaitsmine ühes Lääne-Saksamaa ülikoolis (Padel 1991, tõsi küll, kaitsja oli üks eestlasest tudeng), ilmus kirjandusteaduslikke käsitlusi (nt Scholz 1996) ja valmis esimene saksakeelne väitekiri Krossist (Wagner 2001, tõsi, jälle eestlasest kaitsja sulest; väitekirja kohta vt Maier 2004; Hasselblatt 2015b: 401-404). Rööbiti ilmusid erinevates ajakirjades esseistlikud käsitlused (nt Gauß 1992; Raubold 1992; Wulff 2004), samuti autori novellide tõlked (Kross 1990a, 1993a, 1994b). Kõige suurema leviku saavutasid arvatavasti kaks Krossi esseed, mis ilmusid suures päevalehes Leipzigi raamatumessiks aastal 1997 (Kross 1997b, 1997c). Lõpuks pühendati Krossile ruumi mitmes mainekas mitmeosalises käsiraamatus (nt Gräf 1999; Steffens 1999; Hasselblatt 2000) ning ta jõudis koguni populaarsesse kirjanduskalendrisse, kus oli Krossi 85. sünnipäeva puhul tema pilt koos „Keisri hullu” kaanega (Harenberg 2005).

Siiski ei läinud „Rakvere romaaniga” kõik ootuspäraselt. Esialgsed müügiarvud olid küll samad nagu eelmistel romaanidel (Hasselblatt 2011: 333), kuid kirjastus oli ilma konkreetse põhjuseta, võib-olla lihtsalt vahelduseks kujundust vahetanud. Kolm eelmist Hanseri kirjastatud Krossi teost oli kujundanud tuntud raamatukunstnik Quint Buchholz, nii et raamatud sarnanesid üksteisega. Nüüd, neljandal aga ei olnud kaanel enam Buchholzi joonistus, vaid kuulus Jan Vermeeri maal „Tütarlaps pärlkõrvarõngaga” (1665). Ilmselt taheti kuulsa maali reproduktsiooniga tõsta müügiedu, nagu ka reklaamiva tutvustusega, sest väljaande tagakaanele oli kirjastus lasknud trükkida, et see on „suure eesti autori üks ilusamaid ajaloolisi romaane, selgelt ja peenetundeliselt jutustatud, maailmakirjanduse raamat" (Kross 1997a).

Ka Eesti kontekstis oli see romaan tegelikult pisut erandlikus positsioonis, mis kajastus üsna madalas arvustuste arvus (11, vt Kabur, Palk 1997: 159160), eriti võrreldes eelmise ja järgneva romaaniga, „Keisri hullu” ja „Professor Martensiga” (Kabur, Palk 1997: 155-162, kus on 48 kirjet „Keisri hullu” ning 22 kirjet „Professor Martensi” kohta). Teine erinevus on sisulist laadi. Peaaegu kõigis teistes romaanides on keskne mingi ajalooline isik - Russow, von Bock, 
Martensid, Sittow, Michelson, Masing, Peterson, Schmidt, Vilms jne -, aga „Rakvere romaanis” mitte. Seal on keskmes hoopis linn, ning üheks peategelaseks ja jutustajaks on keskpärane, tavaline, pealegi väljamõeldud Berend Falck. Kuigi romaani sügavamat sõnumit ning vabaduse temaatikat on tähele pandud juba kaasaegses kriitikas (nt Jõerüüt 1983) ja Juhani Salokannel (2008: 212) on „Rakvere romaani” nimetanud Krossi kõige allegoorilisemaks romaaniks, võib eeltoodu olla üheks põhjuseks, miks saksa kriitika ei olnud nii vaimustatud nagu varem. Samastumisvõimalus kangelastega polnud enam nii selge, polnud üldsegi mingit kangelast, kellega lugejal oleks tänu Krossi avastustele olnud võimalik tutvuda.

See, muide, kajastus juba minu meelest tõlke kohmakas pealkirjas: „Rakvere naised ehk Kodanike ülestõus” („Die Frauen von Wesenberg oder Der Aufstand der Bürger”), mis ongi seesama, millega autor ise artikli alguses toodud tsitaadis polemiseerib. Ilmselt sai ka Kross aru kirjastuse kaalutlusest, et kohanimi nagu Rakvere ei ütle saksa lugejale midagi, ka selle (veel tundmatumas) saksa kuues mitte. Muidugi ei pruugi see olla alati määrav - rootsi ja vene tõlked säilitasid Rakvere, kuigi tavaline rootslane ega tavaline venelane ei tea, kus selline koht asub -, aga Saksamaal on üldiselt kirjastajatel viimane sõna, kui kõne all on pealkiri. Kirjastajad tahavad raamatuga ometi raha teenida - asjaolu, millele ka autor ise vist poleks vastu olnud. Ning Hanseri kirjastuse inimesed kartsid, et ainult „Rakvere” või „Wesenbergiga” kasu vist ei tule, ning panid pikema ja laialivalguva topeltpealkirja märksõnadega „naised” ja „mäss”. Pluss silmatorkav kaanepilt, mida kõik tunnevad. Teiste sõnadega: kirjastajad ei usaldanud „oma” autorit, nad kartsid, et ainult kirjaniku nimest on vähe. Kahjuks turg ei anna teist šanssi ja me ei saa kunagi teada, kuidas oleks müüdud ja vastu võetud teost, millel olnuks Buchholzi tuttavlik ja kaine kaanekujundus ning originaalile vastav pealkiri „Der Roman von Rakvere”. Ent nüüd ei ole välistatud, et just tõlke pealkiri koos klassikalise, aga seeläbi triviaalselt mõjuda võiva kaanega avaldas mõju arvustajatele.

Puhtkvantitatiivselt oli arvustusi ilmselt umbes sama palju kui eelnevatele tõlgetele (vt Kabur, Ritson 2006: 131-133, kus on üles loetud isegi 28 kirjet), aga kõige silmapaistvam erinevus retseptsioonis oli see, et suuremaist kriitikaväljal tegutsejaist puudus oluline osa. Sellele lisandus tõik, et kaks tooniandvates ajalehtedes ilmunud arvustust polnud eriti positiivsed. Kriitika polnud küll lausa mahategev, aga ka leige või ükskõikne arvustus võib mõjuda raamatu edule negatiivselt.

Die Zeitis uhkustas arvustaja oma kirjanduslike teadmistega, nimetades peaaegu kümmekond kirjanikku, kes kõik oskavad tema meelest Krossist paremini kirjutada (James Joyce, Walter Scott, Thomas Mann, Robert Musil, Hermann Broch, Thomas Bernhard, Umberto Eco, Gabriel García Márquez), ja leidis pettunult, et iseenesest põnev lugu on väsitav: Scott oleks seda paremini teinud (Lützeler 1997). See arvustus oli pigem ükskõikne ja vähemalt pealkirja poolest neutraalne, mida ei saa öelda Süddeutsche Zeitungi arvustuse kohta, kus autor mõisteti hukka juba pealkirjas: „Happy end'iks püksid maha”, ning alapealkirjas: „Jaan Kross jutustab seebikat võistlusest linna pärast" (Göttler 1997). Arvustus ise polnudki nii negatiivne, kui oleks võinud pealkirja põhjal oletada, vaid pigem leige ja pisut igavlev, kriitik ei olnud pahatahtlik, aga ta rääkis ka „külanaljandist” ja sellest, et kurb poliitiline jant muutub lõpuks love story'ks. 
Kuigi tõin ainult kaks näidet suuremast arvustuste korpusest ning umbes samal ajal ilmus kolmandas tähtsas lehes, Neue Zürcher Zeitungis, ulatuslik ja kiitev artikkel Krossi kohta, milles ka „Rakvere romaani” väga positiivselt mainiti (Matt 1997), piisas nendest kergelt negatiivsetest arvustustest, et kirjastus loobuks kavandatud taskuväljaandest (Hasselblatt 2011: 333). Enamgi: ka algselt kavandatud - juba tõlgitud ja tasutud - järgmised Krossi romaanid jäid seisma, kuni kirjastus nende kirjastamisõigused XXI sajandi algul tagasi andis ning Krossi teoste avaldamisest koguni loobus. „Rakvere romaan” oli neljas ja viimane Hanseri kirjastuses ilmunud Jaan Krossi romaan.

\section{Ja edasi? Mõned seletuskatsed}

Muidugi ei lõppenud kogu Jaan Krossi retseptsioon Saksamaal paugupealt. Mõned raamatud veel ilmusid, kõigepealt „Keisri hullu” uusväljaanne Süddeutsche Zeitungi romaanisarjas (Kross 2007a), mis tähendab, et selle romaani kogutrükiarv Saksamaal oli umbes 60000 (Hasselblatt 2011: 320). Kui Kross 2007. aasta detsembris suri, oli ta saavutanud saksa kirjandusväljal positsiooni, millist ükski teine eesti kirjanik ei olnud varem ega ole ka hiljem saavutanud. Ajakirjanikel olid enamasti nekroloogid sahtlis valmis, nii et teda - veel viimat korda - meenutati mitmes kohas.

Selsamal aastal ilmus Tallinnas novellikogumik (Kross 2007b) kaheksa saksa keelde tõlgitud novelliga, millest aga seitse olid juba varem, enamasti rohkem kui üks kord, ajakirjanduses ja antoloogiates ilmunud. Kuid see, nagu ka kolm aastat varem ilmunud lasteraamat (Kross 2004b), kuulub jällegi pseudoretseptsiooni valda, ja mitte üksnes sellepärast, et tõlgete tase on osaliselt ebarahuldav.

Selmet retseptsioon ka pärast autori surma rahulikult edasi läheks nagu mitmes muus keeles juhtub, näiteks ilmus alles hiljuti hispaaniakeelne „Paigallend” (Kross 2015) -, jäi see saksa kirjandusväljal seisma. Selleks pole üht kindlat põhjust, küllap tekitas sellise olukorra rea seikade kokkusattumine.

Esiteks oli üks negatiivne tegur lõputu Nobeli auhinna ootamine ja lõpuks selle mittesaamine (vrd Valton 2015: 1737). Nobeli laureaati võib ka surnuna turustada, selle mittesaajat ei taheta aga nii väga avaldada. Ent see käib juba kõikide maade kohta, nii et Krossi saksa retseptsiooni soikumise seletusena on see puudulik.

Teiseks, iga kirjanik ja iga teos on vastuvõtlik kriitikale, sest see on kirjanduselu ja kirjandusvälja oluliselt määrav tegur. Keegi ei ole sellest sõltumatu. Enamasti oli Krossi teoste kriitika väga positiivne, osaliselt eriti kiitev või juubeldav. Aga piisas ühe romaani kohta kahest otsustavates väljaannetes ilmunud tagasihoidlikust, kergelt negatiivsest ja siiski mitte päris mahategevast arvustusest, et kirjastus kohkunult pidurdas ning loobus oma plaanidest algul osaliselt ja ajutiselt, hiljem aga lõplikult.

Kolmandaks, sellest tekkis teatud patiseis, sest valmis tõlked olid olemas, aga avaldamisõiguste omanik ei teinud nendega midagi. Teised, kes oleksid ehk tahtnud või julgenud, ei tohtinud midagi ette võtta. Tekstid seisid, retseptsioon puudus. Kui autoriõigused mõne aasta pärast tagastati või vabaks lasti, oli hilja. Selline olukord oli saksa kirjandusväljal tõepoolest teistmoodi kui kõigi muude keelte puhul. 
Ja neljandaks, lõhestumine erinevate kirjastuste vahel pigem segas, kui soodustas Krossi saksakeelset retseptsiooni. Kui kurvalt see ka ei kõla, on see kui mitte otsene, siis vähemalt kaudne nõukogude pärand. Kui Eesti okupeeriti 1940. aastal, „sai” ta endale ka nõukogude õigussüsteemi. Kirjanduse valdkonnas oli tähtis, et Nõukogude Liit polnud kunagi liitunud Berni lepinguga ning ühines alles aastal 1973 „Ülemaailmse autoriõiguse konventsiooniga” (Universal Copyright Convention, Genf 1952). Siis asutati Moskvas ka VAAP, mille alla käis välismaa ja tõlgetega tegelemine. Nõukogude kodanikel endil polnud ju asja välismaale.

Asi läks aga veel keerulisemaks, kuna VAAP tegi vahet sotsialistlike ja kapitalistlike maade vahel. Soome kirjastusega WSOY oli Kross alla kirjutanud lepingu, mis andis WSOY-le õigused kogu läänemaailma jaoks. Saksamaa oli sellest lepingust aga välja jäetud sel lihtsal põhjusel, et Saksamaa ju ei olnud lääs, või oli seda ainult osaliselt, oli olemas ka sotsialistlik Saksamaa, millega võidi teistmoodi ümber käia või kaubelda. Kui Saksa DV (ning varsti Nõukogude Liit) olid kadunud, võttis Hanser - muidugi autoriga kooskõlastades ning temaga lepingugi tehes - Saksa DV-s ilmunud tekstid pärandina üle ning lubas edaspidi Krossi tekste levitada. Kuid Jaan Kross oli jätnud endale õiguse ka teiste võimalike kirjastajatega rääkida. See on muidugi iga autori, kes on oma tekstide looja ja omanik, õigus, aga see on lääne kirjandusväljal suhteliselt ebatavaline. Ainult sellepärast saigi juhtuda, et samal aastal ilmus kaks sama pealkirjaga raamatut erineva sisuga ning erinevates kohtades. See tõi endaga kaasa lõhenemise, mis ilmselt ei tulnud autorile kasuks.

Minu meelest mitte ükski neist eelmainitud seletamiskatsetest poleks üksinda olnud suuteline kõigutama Jaan Krossi kõrgetasemelise loomingu vastuvõttu mingis keeleruumis. Aga nende kokkusattumine seletab seda, miks Jaan Krossi teoste vastuvõtt saksa keelealal on aastal 2016 nigelam kui mitmel teisel keelealal.

\section{Kirjandus}

B ourdieu, Pierre 1983. The field of cultural production, or: the economic world reversed. - Poetics, nr 12, lk 311-356.

B o u r d i e u, Pierre 1985. The market of symbolic goods. - Poetics, nr 14, lk 13-44. Brä u er, Margit 1990. Im Fokus der Geschichte ein humaner Zukunftsentwurf. - Der Verrückte des Zaren. Jaan Kross in Loccum. Olaf Schwencke (toim). Loccum: Evangelische Akademie, lk 109-117.

Bucheli, Roman 1995. Zwischen drei Pestseuchen. - Neue Zürcher Zeitung (Internationale Ausgabe) 10. X, nr 235, lk B8.

B ur me is t er, Angela 1990. Estnische Literatur in Deutschland und in der Deutschen Demokratischen Republik von Beginn des 20. Jahrhundert [sic] bis Ende der achtziger Jahre. Dissertation A zur Erlangung des akademischen Grades Doktor eines Wissenschaftszweiges (doctor philosophiae) vorgelegt dem Wissenschaftlichen Rat der Wilhelm-Pieck-Universität Rostock.

Drawic z, Andrzej 1979. „Estnischer Morgentau”. Über das Schaffen des sowjetestnischen Schriftstellers Jaan Kross. - Osteuropa, nr 1, lk 37-43.

EKSS $=$ Eesti keele seletav sõnaraamat 6. Toim Margit Langemets, Mai Tiits, Tiia Valdre, Leidi Veskis, Ülle Viks, Piret Voll. Eesti Keele Instituut. Tallinn: Eesti Keele Sihtasutus, 2009. 
G a u ß, Karl-Markus 1992. Kein Glück im stillen Winkel Europas. Die Romane des estnischen Erzählers Jaan Kross. - Die Neue Gesellschaft. Frankfurter Hefte, nr 9, lk 861-863.

G a u ß, Karl-Markus 1995. Gefährliche Chroniken. - Die Zeit 13. X, nr 42, kirjanduslisa, lk 24.

Goes, Gudrun 1989. Jaan Kross und die Geschichte. - Baltische Sowjetliteraturen. Leistungen, Probleme und Wirkung. Beiträge der Arbeitstagung des Wissenschaftsbereiches Slawistik der Sektion Sprach- und Literaturwissenschaft der Ernst-Moritz-Arndt-Universität Greifswald vom 28./29. Oktober 1986 in Rostock. (Wissenschaftliche Beiträge der Ernst-Moritz-Arndt-Universität Greifswald.) Greifswald, lk 69-74.

Grim m, Gunter 1977. Rezeptionsgeschichte. Grundlegung einer Theorie. München: Wilhelm Fink Verlag.

Gräf, Bernd 1999. Der Verrückte des Zaren. Das Leben des Balthasar Rüssow. - Der Romanführer. Der Inhalt der Romane und Novellen der Weltliteratur. Band 34: Ost-, südost- und nordeuropäische Erzählprosa aus den Jahren 1989 bis 1995. Toim Bernd Gräf. Stuttgart: Anton Hiersemann, lk 96-98.

Göttle r, Fritz 1995. Sei kein Narr. Der estnische Schriftsteller Jaan Kross wird 75. - Süddeutsche Zeitung 18./19. II.

Göttler, Fritz 1996. Verstehen, das schmeckt wie Johannisbrot. - Süddeutsche Zeitung 11./12. V.

Göttler, Fritz 1997. Hosen runter zum Happy-End. Jaan Kross erzählt eine „Soapopera” vom Kampf um eine Stadt. - Süddeutsche Zeitung 12. XI, lisa, lk V.

Harenberg 2005 = Harenberg Literatur Tageskalender, 19. II.

Hass elblatt, Cornelius 2000. Jaan Kross. - Kritisches Lexikon zur fremdsprachigen Gegenwartsliteratur. 51. Nachlieferung. München: edition text + kritik.

Hasselblatt, Cornelius 2004. Estnische Literatur in deutscher Sprache 17842003. Bibliographie der Primär- und Sekundärliteratur. Bremen: Hempen Verlag.

Hasselblatt, Cornelius 2011. Estnische Literatur in deutscher Übersetzung. Eine Rezeptionsgeschichte vom 19. bis zum 21. Jahrhundert. Wiesbaden: Harrassowitz.

H a s s elblatt, Cornelius 2015a. 150 Bücher in 150 Jahren. Zur Rezeption der estnischen Literatur im deutschsprachigen Raum. - Deutsche Akademie für Sprache und Dichtung, Jahrbuch 2013/2014. Darmstadt: Wallstein Verlag, lk 52-75.

$\mathrm{H}$ a s s elblatt, Cornelius 2015b. Eemalt vaadates. Veerand sajandit eesti kirjandusega. (Studia litteraria Estonica 15.) Tartu: Tartu Ülikooli Kirjastus.

Hasselblatt, Cornelius 2016. Kalevipoeg Studies. The Creation and Reception of an Epic. (Studia Fennica Folkloristica 21.) Helsinki: Finnish Literature Society, SKS.

Jõ e r ü üt, Jaak 1983. Kakssada aastat hiljem. - Looming, nr 5, lk 710-711.

Kabur, Vaime, Palk, Gerli (koost) 1997. Jaan Kross. Bibliograafia. [HamburgTallinn]: Bibliotheca Baltica.

Ka bu r, Vaime, Rit s o n, Tiina (koost) 2006. Jaan Kross. Bibliograafia 1997-2005. Tallinn: Eesti Rahvusraamatukogu.

Kangro, Bernard 1954. Flucht und Bleibe. Gedichte in Auswahl. Deutsch von Hermann Stock. Lund: Eesti Kirjanike Kooperatiiv.

Klüger, Ruth 1994. Geschunden und gebeutelt. - Frankfurter Allgemeine Zeitung $1 . \mathrm{X}$. 
Kross, Jaan 1971. Vier Monologe anno domini 1506. - Sowjetliteratur, nr 8, lk 80-108.

Kros s, Jaan 1972. Zwischen drei Pestseuchen. - Sowjetliteratur, nr 8, lk 100-116. Kros s, Jaan 1974. Vier Monologe Anno Domini 1506. Historische Novellen. Aus dem Russischen übersetzt von Hilde Angarowa und Werner Creutziger. BerlinWeimar: Aufbau-Verlag.

Kro s s, Jaan 1976. Der Himmelsstein. - Sowjetliteratur, nr 9, lk 3-91.

Kross, Jaan 1979. Der Himmelsstein. - Als die Wale fortzogen. Koost Margit Bräuer. Berlin-Weimar: Aufbau-Verlag, lk 319-480.

Kr o s s, Jaan 1983. Aufruhr im Adelspalast. - DSF-Journal (Berlin), nr 2, lk 36-39.

Kross, Jaan 1985. Vier Monologe anno domini 1506. Historische Novellen. Aus dem Russischen von Hilde Angarowa und Werner Creutziger. Lektorat: Cornelius Hasselblatt. (Sammlung Trajekt 20.) Helsinki: Otava; Stuttgart: KlettCotta.

Kross, Jaan 1986. Das Leben des Balthasar Rüssow. Historischer Roman. Aus dem Estnischen übersetzt von Helga Viira. Aus dem Russischen übersetzt von Barbara Heitkam. Berlin: Rütten \& Loening.

Kross, Jaan 1988. Der Verrückte des Zaren. Historischer Roman. Deutsch von Helga Viira. Berlin: Rütten \& Loening.

Kross, Jaan 1989. Le fou du tzar. Traduit de l'estonien par Jean-Luc Moreau. Paris: Laffont.

Kros s, Jaan 1990a. Der Aschenbecher. Aus dem Estnischen von Cornelius Hasselblatt. - Trans Atlantik, nr 2, lk 76-83.

Kross, Jaan 1990b. Der Verrückte des Zaren. Roman. Aus dem Estnischen von Helga Viira. München-Wien: Hanser.

Kros s, Jaan 1992. Professor Martens' Abreise. Roman. Aus dem Estnischen von Helga Viira. München-Wien: Hanser.

Kros s, Jaan 1993a. Der estnische Charakter. Aus dem Estnischen von Irja Grönholm. - Sinn und Form, nr 1, lk 79-107.

Kr o s s, Jaan 1993b. Die Verschwörung. Übersetzung aus dem Estnischen. Viktor Sepp. Tallinn: Bibliotheca Baltica.

Kros s, Jaan 1994a. Der Verrückte des Zaren. Historischer Roman. Deutsch von Helga Viira. München: Deutscher Taschenbuch Verlag.

Kr o s s, Jaan 1994b. Die Flucht. - Sinn und Form, nr 2, lk 165-183.

Kross, Jaan 1994c. Die Verschwörung. Erzählungen. Aus dem Estnischen von Irja Grönholm und Cornelius Hasselblatt. Frankfurt/M.: Dipa.

Kros s, Jaan 1995a. Ausgrabungen. Roman. Aus dem Estnischen von Cornelius Hasselblatt. Frankfurt/M.: Dipa.

Kr o s s, Jaan 1995b. Das Leben des Balthasar Rüssow. Roman. Übersetzt von Helga Viira und Barbara Heitkam. München-Wien: Hanser.

Kros s, Jaan 1995c. Professor Martens' Abreise. Roman. Deutsch von Helga Viira. München: Deutscher Taschenbuch Verlag.

Kr o s s, Jaan 1996. Das Leben des Balthasar Rüssow. Roman. Übersetzt von Helga Viira und Barbara Heitkam. Frankfurt/M.-Wien: Büchergilde Gutenberg.

Kros s, Jaan 1997a. Die Frauen von Wesenberg oder Der Aufstand der Bürger. Roman. Aus dem Estnischen von Helga Viira. München-Wien: Hanser.

Kros s, Jaan 1997b. Die Wüstenwanderung des estnischen Volkes. Aus dem Estnischen von Cornelius Hasselblatt. - Frankfurter Rundschau, Literatur-Rundschau, 19. III, lisa, lk 1. 
Kross, Jaan 1997c. Schriftsteller eines kleinen Volkes. Aus dem Estnischen von Irja Grönholm. - Handelsblatt / Der Tagesspiegel. Literatur. Beilage zur Leipziger Buchmesse 1997, 19. III, lk 1.

Kros s, Jaan 1999. Das Leben des Balthasar Rüssow. Roman. Deutsch von Helga Viira und Barbara Heitkam. München: Deutscher Taschenbuch Verlag.

Kros s, Jaan 2003a. Der Verrückte des Zaren. Historischer Roman. Deutsch von Helga Viira. München: Deutscher Taschenbuch Verlag.

Kros s, Jaan 2003b. Omaeluloolisus ja alltekst. 1998. a. Tartu Ülikooli filosoofiateaduskonna vabade kunstide professorina peetud loengud. Tallinn: Eesti Keele Sihtasutus.

Kross, Jaan 2004a. Der Verrückte des Zaren. Historischer Roman. Deutsch von Helga Viira. München: Deutscher Taschenbuch Verlag.

Kros s, Jaan 2004b. Marts Brot oder Wie das Marzipan erfunden wurde. Übersetzung aus dem Estnischen. Aivo Kaidja. s.l.: Bibliotheca Baltica.

Kross, Jaan 2007a. Der Verrückte des Zaren. Roman. Aus dem Estnischen von Helga Viira. (Süddeutsche Zeitung I Bibliothek 78.) München: Süddeutsche Zeitung.

Kross, Jaan 2007b. Die Stahl'sche Grammatik. Erzählungen. s.l.: Bibliotheca Baltica.

Kros s, Jaan 2015. Vuelo estático. Trad. Consuele Rubio Alcover. Madrid: Impedimenta.

Kr u m m, Reinhard 1995. Jaan Kross: Den Mächtigen die Wahrheit sagen. - Neue Zürcher Zeitung 18./19. II.

Li a s, Pärt 1971. Balthasar Russow' köietrikk. - Keel ja Kirjandus, nr 4, lk 238241.

Links, Christoph 2009. Das Schicksal der DDR-Verlage. Die Privatisierung und ihre Konsequenzen. Berlin: Ch. Links Verlag.

Lützeler, Paul Michael 1997. Macht will an der Macht sein. Jaan Kross' historischer Roman „Die Frauen von Wesenberg”. - Die Zeit 17. X, lk 22.

Maier, Konrad 2004. [teose Wagner 2001 pealkirjata arvustus.] - Finnisch-Ugrische Mitteilungen, $\mathrm{nr}$ 26/27, lk 217-219.

Matt, Beatrice von 1997. Reise zu einem ungekrönten König. Gespräch mit dem estnischen Schriftsteller Jaan Kross. - Neue Zürcher Zeitung (Internationale Ausgabe) 8. XII, lk 23.

Mägi, Arvo 1968. Estonian Literature. Stockholm: The Baltic Humanitarian Association.

Neidhart, Christoph 1988a. Revals Undeutsche unter der Fuchtel. - Die Weltwoche 25. II, nr 8, lk 53.

Neid hart, Christoph 1988b. Die Undeutschen von Reval. - Rheinischer Merkur 29. VII, nr 31, lk 13.

Or a s, Ants (koost) 1964. Acht estnische Dichter. Ausgewählt und übertragen von Ants Oras. Stockholm: Verlag Vaba Eesti.

Padel, Anja 1991. Rekonstruktion und Ästhetisierung von Geschichte. Die Geschichte Estlands 1560-1584 bei Balthasar Russow und Jaan Kross. [Magistritöö.] Kiel.

Raubold, Susanne 1992. Jaan Kross: „Wer etwas Wesentliches will, bleibt zu Hause". - Du. Die Zeitschrift der Kultur, nr 12, lk 28-31.

Salok a nnel, Juhani 2008. Sivistystahto. Jaan Kross, hänen teoksensa ja virolaisuus. Helsinki: WSOY. 
Scholz, Friedrich 1996. Die Befreiung des Wortes und die Befreiung durch das Wort. Zum Werk und Wirken des estnischen Dichters Jaan Kross. - Contacts de langues et de cultures dans l'aire baltique. Contacts of Languages and Cultures in the Baltic Area. Mélanges offerts à Fanny de Sivers. M. M. Jocelyne Fernandez, Raimo Raag (toim). (Uppsala Multiethnic Papers 39.) Uppsala, lk 227-241.

Schubert, Christel 1994. Lesereise von Jaan Kross. - Estonia, nr 2, lk 46-47.

S chwencke, Olaf (toim) 1990. Der Verrückte des Zaren. Jaan Kross in Loccum. (Loccumer Protokolle 58/'89.) Loccum: Evangelische Akademie.

S e r ke, Jürgen 1990. Sei mein Narr, Timotheus! Selbstbewußte Signale aus Reval: Porträt des estnischen Schriftstellers Jaan Kross. - Die Welt 4. VIII, lk 21.

Steffens, Monika 1999. Ausgrabungen. - Der Romanführer. Der Inhalt der Romane und Novellen der Weltliteratur. Band 34: Ost-, südost- und nordeuropäische Erzählprosa aus den Jahren 1989 bis 1995. Toim Bernd Gräf. Stuttgart: Anton Hiersemann, lk 98-100.

T a u be, Arved von 1977. [pealkirjata] - Jahrbuch des baltischen Deutschtums 25 (1978), lk 200-205.

Trajekti toimetus 1983 = Trajekti toimetuse kiri C. Hasselblattile 21. XI 1983.

V alt o n, Arvo 2015. Mälestuskilde kirjanikest. - Looming, nr 12, lk 1728-1747.

Vei p e r, Ene 1990. Jaan Krossi reisid. - Reede 21. XII, nr 51.

Verg, Erik 1985. Ein Autor sucht Freunde seines Romanhelden. Schriftsteller Jaan Kross in Hamburg. - Hamburger Abendblatt 31. X.

W agner, Kerttu 2001. Die historischen Romane von Jaan Kross. Am Beispiel einer Untersuchung der deutschen und englischen Übersetzungen von Professor Martensi ärasõit (1984). (Europäische Hochschulschriften, Reihe XVIII: Vergleichende Literaturwissenschaft, Bd. 97.) Frankfurt/M. et al.: Peter Lang.

Wulf, Meike 2016. Shadowlands. Memory and history in post-Soviet Estonia. Oxford-New York: Berghahn Books.

Wu lff, Erich 2004. Im Ungreifbaren überleben. Zu Jaan Kross' Roman Tabamatus. - Das Argument, nr 258, lk 850-856.

Wölfel, Ute (koost) 2005. Literarisches Feld der DDR. Bedingungen und Form literarischer Produktion in der DDR. Würzburg: Königshausen \& Neumann.

\section{Funktionsweisen des literarischen Feldes am Beispiel der deutschen Rezep- tion von Jaan Kross}

Stichwörter: Rezeption, Übersetzung, Literarisches Feld, Pierre Bourdieu, Jaan Kross, Deutschland

Der Artikel beruht auf den entsprechenden Kapiteln der Monographie des Autors (2011) über die Rezeption der estnischen Literatur im deutschsprachigen Raum, ist aber stellenweise gekürzt, bearbeitet und weiterentwickelt. Da von Jaan Kross vergleichsweise viele Bücher auf Deutsch vorliegen, bietet sich sein Werk für eine eingehendere Rezeptionsanalyse an. Im Vordergrund stand dabei die Frage, warum die zwischenzeitlich sehr lebhafte Rezeption zu Beginn des 21. Jahrhunderts erlahmt ist. Hierzu wird die Theorie des literarischen Feldes von Pierre Bourdieu angewendet, anhand deren untersucht wird, welche Rolle die jeweiligen Akteure auf dem Rezeptionsfeld gespielt haben. In erster Linie werden Verlage und Kritiker 
in Abhängigkeit von ihrer Position auf dem literarischen Feld betrachtet, ferner inhaltliche Aussagen der Kritik und begrenzt auch quantitative Angaben. Im Ergebnis scheint es vier Faktoren zu geben, die in ihrer Addition eine spezifische Situation für die deutsche Rezeption von Jaan Kross geschaffen haben, die auf andere Länder nicht zutrifft und die sich nachteilig auf die Aufnahme der Werke des Autors ausgewirkt hat: Das Nicht-Bekommen des Nobelpreises (trifft freilich für alle Länder zu), zurückhaltende Aufnahme eines Romans in tonangebenden Medien, infolgedessen Verzögerung der Herausgabe der weiteren Werke, und schließlich die Aufspaltung zwischen verschiedenen Verlagen.

Cornelius Hasselblatt (geb. 1960), PhD, 1998-2014 Professor für finnougrische Sprachen und Kulturen an der Universität Groningen, cornelius@hasselblatt.com 